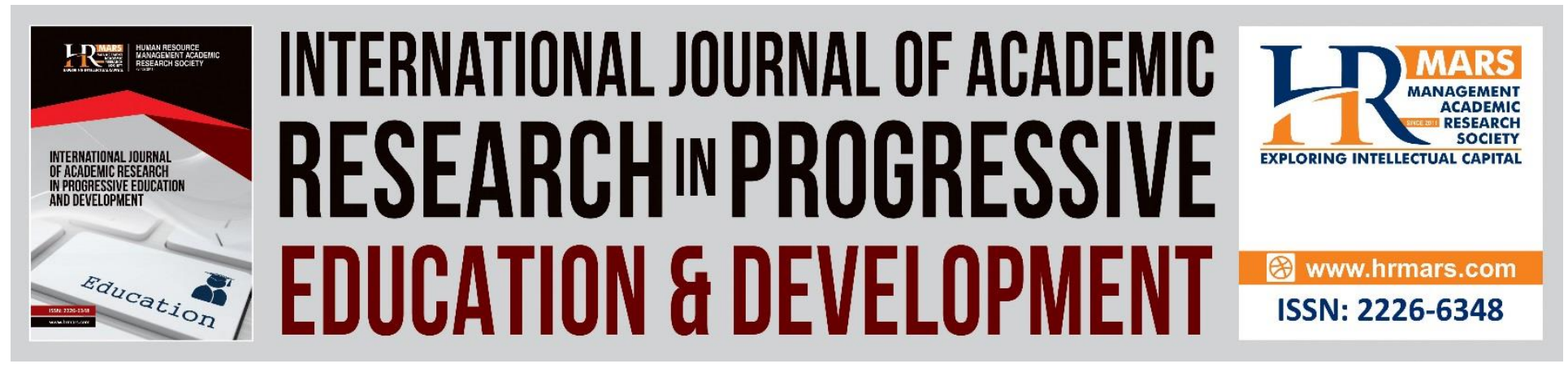

\title{
Factors Influencing ICT Competency Skills among ESL Primary School Teachers
}

Nadzirah Saimi, Hamidah Yamat

To Link this Article: http://dx.doi.org/10.6007/IJARPED/v10-i1/8829

DOI:10.6007/IJARPED/v10-i1/8829

Received: 30 December 2020, Revised: 26 January 2021, Accepted: 15 February 2021

Published Online: 28 February 2021

In-Text Citation: (Saimi \& Yamat, 2021)

To Cite this Article: Saimi, N., \& Yamat, H. (2021). Factors Influencing ICT Competency Skills among ESL Primary School Teachers. International Journal of Academic Research in Business and Social Sciences, 10(1), 220-236.

Copyright: (C) 2021 The Author(s)

Published by Human Resource Management Academic Research Society (www.hrmars.com)

This article is published under the Creative Commons Attribution (CC BY 4.0) license. Anyone may reproduce, distribute, translate and create derivative works of this article (for both commercial and non-commercial purposes), subject to full attribution to the original publication and authors. The full terms of this license may be seen

at: http://creativecommons.org/licences/by/4.0/legalcode

Vol. 10(1) 2021, Pg. 220 - 236

http://hrmars.com/index.php/pages/detail/IJARPED

JOURNAL HOMEPAGE

Full Terms \& Conditions of access and use can be found at http://hrmars.com/index.php/pages/detail/publication-ethics 


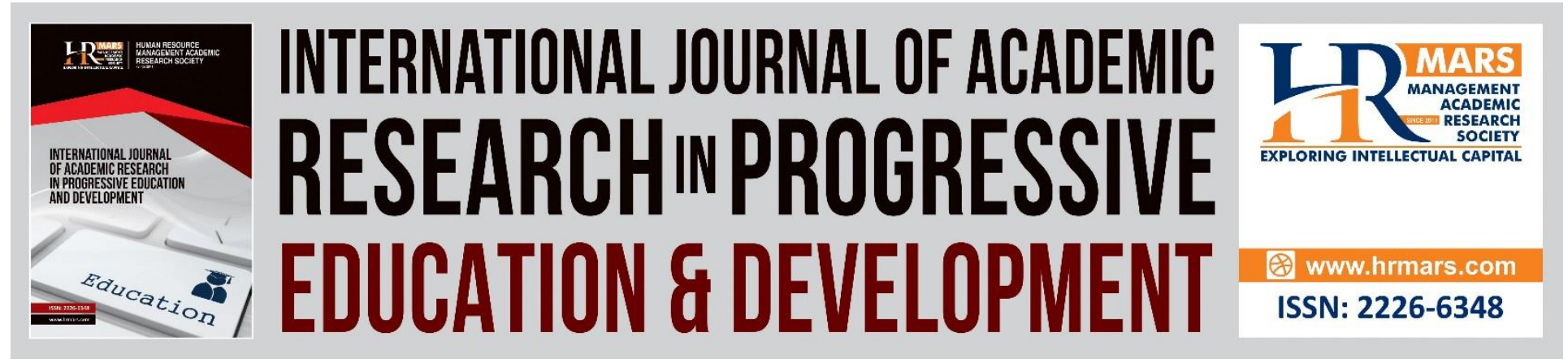

\title{
Factors Influencing ICT Competency Skills among ESL Primary School Teachers
}

\author{
Nadzirah Saimi \\ Faculty of Education, Universiti Kebangsaan Malaysia, 43600 UKM, Bangi Selangor, Malaysia. \\ Email: nadzirahsaimi@gmail.com \\ Hamidah Yamat \\ Faculty of Education, Universiti Kebangsaan Malaysia, 43600 UKM, Bangi Selangor, Malaysia. \\ Email: hamidah_yamat@ukm.edu.my
}

\begin{abstract}
In this era where integration of ICT has become crucial in education sector, there is a need of educators and teachers to acquire skills and achieve certain level of ICT competency. Therefore, this study is designed with the aim to identify the level of Information and Communications Technology (ICT) competency skills and determine the factors influencing the competency skills among English as Second Language (ESL) teachers in the context of rural teachers teaching in the district of Mukah. This research is using quantitative research design in answering the research questions. There are 80 respondents from district of Mukah participated in answering the survey questionnaire for this research. The findings of this study highlighted the level of ICT competency skills of the ESL primary school teachers which are developing to proficient level. Other than that, the findings also clarify the factors that influenced the ICT competency skills are teachers' attitudes and also accessibility and technical support in schools. Implications of this research are ESL teachers come to recognise and realise their level of ICT competency skills. Apart from that, the implication of this research also involved the administrators' responsibility in optimising the integration of ICT in ESL classroom.
\end{abstract}

Keywords: ICT, ESL, ICT Competency Skills, ESL Teachers, Technology

\section{Introduction}

In modern era, information and communication technology (ICT) competency has been getting a lot of attention in educational programmes and institution in most countries in the world. In Philippines for instance, National ICT Competency Standard (NICS) has been issued for teachers in order to show support to ensure the significance of ICT competency in education among teachers and students (Guillo \& Guillo, 2017). This program by the Philippines proved that ICT competency is needed among teachers and students to prepare them for future education. 
Learning strategies in education for all levels may change in near future and will involve the use of technology due to various modern technology available nowadays.

Meanwhile in Malaysia, the Ministry of Education (MoE) has included "Leverage of ICT to Scale Up Quality Learning Across Malaysia" as one of the 11 strategic initiatives in order to enhance the quality of education in Malaysia. In this initiative, the MoE has stated that the government along with the MoE will ensure that the use of ICT is maximised for distance and selfpaced learning in order to expand capacity and allow for more customised learning for the pupils (Ministry of Education 2013). These new initiatives showed that the education policy in Malaysia is getting a brand-new change and moving towards an education associated with the use of technology. The initiative of maximising integration of ICT will require the teachers' readiness in terms of skills, competency and knowledge in ICT tools or software. It is only logical to witness the integration of ICT in classroom when the teachers are supplied with ample level of ICT competency.

Therefore, the current study is designed to fulfil the needs of identifying the level of ICT competency among ESL primary school teachers. The needs of identifying the level of ICT competency are also supporting the findings from a study conducted by Anas and Musdariah (2018). Whereby, in order to be able to use ICT instruments in language teaching and learning, ESL teachers should develop their technological competencies and skills. It is also beneficial to determine the possible factors which influence the level of ICT competency by of the ESL primary teachers.

\section{ICT Competency}

In a recent study report by Luque, Abdurrahman and Prakosa (2020), they highlighted the importance of having competency in skills required in modern days. Apart from that, in the report also mentioned that the competency standards for human capital is necessary in developing the skills required in modern era. The context of their study involves the TVET community and management. The research did highlight that competencies often lay the foundation for skill standards which specify the level of knowledge, skills and experience possessed for workplace success as well as potential measurement criteria for assessing competency achievement. It can be concluded that a person who have competency in certain skills can be considered as having the foundation of necessary skills and knowledge in ensuring success in workplace.

Meanwhile in a study conducted by Kasemsap (2018), he has been focusing on the encouragement of digital literacy and also ICT competency in this information age or modern age. In his research study, he viewed ICT competency as expertise, skills and capacity to take advantage of ICT in order to obtain, process and present information to promote activities among various groups in society. Thus, one's competency in ICT can be measured by taking account on their expertise, skills and capacity to use ICT in processing related information. He also addressed the issue of being digital literate and the audacity of acquiring appropriate level of ICT competency in competing in the information age or modern age.

Other than that, Aziz and Rahman (2017) highlighted that in this modern era, there is a need for continued preparation and upgrading of information on recent developments in ICT technologies and software for both teachers and students in order to ensure that the mixture of ICT and teaching activities becomes more polished. To ensure the integration or the use of ICT in 
lessons are regular, teachers or educators need to have good exposure of ICT tools and software as well as the ICT competency. However, in the context of indigenous primary school for this study, the researchers found a huge gab in terms of readiness and knowledge in ICT. Luckily the students have been motivated by the use of ICT by their teachers in schools and also encouraged them to attend schools.

The level of ICT expertise of teachers was assessed by Santiañez, Gumabay \& Pizarro (2019) using the E-Assessment Application, and the regular use of ICT resources by teachers for their lessons was one of the topics used in the E-Assessment Application. The findings of the test revealed that the most frequent ICT instruments were used by teachers, the higher degree of ICT expertise the teachers seemed to have, as can be seen through the E-Assessment Application results.

Looking on a recent research study conducted by Zainal and Zainuddin (2020), the use of technology by teachers can be perceived in terms of frequency and efficiency. At one step, it is important to look at whether teachers in the classroom routinely use ICT. It is also important to look at how they have used ICT in lessons at another stage. Therefore, in this study the number of frequencies in using the ICT tools is influencing the use of technology by teachers. Teachers are required to use the technology regularly in classroom in order to improve their digital literacy and ICT competency skills.

\section{Factors affecting Learning using ICT}

In a research study conducted by Kamaruddin et. al (2017), the finding of the study found out that the successful application of ICT systems obviously depends on the preparation of teachers and even on skilled ICT instruction, and ICT can definitely be more readily integrated by those who find it to be helpful in fostering learning. The readiness of teachers can also be perceived by the attitudes of teacher when handling ICT tools. The teachers should display a successful application of ICT system if they have suitable level of ICT competency and a positive attitude handling the technology.

Aziz and Rahman (2017) in their study related to indigenous primary classroom has highlighted in their findings that there is an inadequate number of ICT facilities such as LCD projectors, time to prepare the lessons and also setup of the session involving the use of ICT tools. These problems or feedbacks from their respondents have been affected by the lack of accessibility on ICT in the classrooms and also insufficient technical support on the ICT integrated lessons. This is also seen as problem involving administrators of the schools. The time constraints of lessons involving ICT integration should administered by the administrators of respective schools. They should be willing to create an ICT policy which caters to the need of teachers in schools. The ICT policy would help the teachers to implement and integrate ICT more in classroom or lessons as well as improving their ICT competency skills.

Other than that, there are also teachers who displayed negative attitudes on ICT competency skills. However, participants that get involved in the research conducted by Kalra are categorised into novice teachers and experienced teachers. Therefore, the responses varied between the categories which can influence the responses of the teachers. Kalra (2018) has stated in his findings that experienced teachers claimed that there is no use of software and ICT tool in their teaching practises. These teachers also did not see the importance of having ICT 
competency skills in their teaching and learning process. Other than that, the use of computer among experienced teachers and novice teachers are slightly different. The experienced teachers used less computer in a month, while novice teacher used it daily. But then again, this study by Kalra is in the Thai context. The result of this current study might not be the same as Kalra's since the current study will be focused on different context.

Administrators also play important part in accommodating the best possible support on ICT tools for teachers. Cheok et al. (2017) stated in their study that administrators have crucial roles in maintaining the eloquence of access to ICT instruments or technologies in classrooms. They will need to ensure the professional assistance that can be provided to ease the lessons of the students. It is also stated in the study that the teachers are supposed to be accompanied with ample of reliable and more effective support from the management which in school should be referred as the school administrators.

\section{Significance and Purpose of Study}

In ESL classroom contexts, the role of information and communication technology (ICT) has been seen as beneficial in finding methods to help administer lesson. This use of ICT could well be an impactful experience in the language classroom (Kalra. 2018). Therefore, the rationale of this study to be conducted is to help the ESL primary school teachers to realise their potential based on their level of ICT competency skills. This will also create opportunities for the teachers to increase their level of ICT competency skills in order to be on par with the modern era and technology. This research study would also be beneficial to the administrators since it helps to improve their action plan for ICT integration in school management and also the integration of ICT in teaching practices. Other than that, the policy makers also get the benefits from this study as they get to evaluate the data and decide on necessary policies regarding the integration of ICT in ESL classroom.

The purpose of this study is to identify the level of ICT competency among ESL primary school teachers and the possible factors that influence the level of ICT competency in sub urban and rural areas. The identification of the level of ICT competency among ESL primary school teachers is crucial in order to clarify the current level of ICT competency among ESL primary school teachers in selected areas. The second part of the study is also relevant in order to decide the factors which influence the level of ICT competency of the ESL primary school teachers.

Therefore, the objectives of the study can be concluded as following:

1. To identify the levels of ICT competency among ESL primary school teachers.

2. To determine factors that influence ICT competency among ESL primary school teachers.

The study is conducted to answer the following questions:

1. What is the level of ICT competency among the ESL primary school teachers?

2. What are the factors that can influence the ICT competency among ESL primary school teachers? 


\section{Methodology \\ Research Design}

Several types of study designs may be utilized in different researches, such as ethnographic designs, sample designs, correlation designs, designs for intervention research, plot designs, and designs for case studies. Based on the challenge and scope the researcher will investigate or discuss, each design will differ from one design to another. For this research, quantitative research design is adopted and adapted in order to answer the research questions involving the level of ICT competency and factors influencing the ICT competency among ESL primary school teachers.

\section{Research Method}

Sample

The sample for this research was chosen using the purposive sampling technique. Purposive sampling technique is perceived as the target group participants who satisfy such functional requirements, such as simple accessibility, geographical proximity, accessibility at a given time or ability to participate in the research, have been chosen to meet the criteria for achieving the study's objectives (Etikan, Musa \& Alkassim 2016). Therefore, since the criteria for sample of this research study is related to ESL primary school teachers, the rightful sample should be teachers teaching English in primary schools. The number of samples of this study is 80 respondents of primary school teachers who teach English subject in schools.

\section{Setting}

The setting of research study refers to the place where the study will take place. In this study, the setting would be in Mukah Division. However, this study will not be involving all district in Mukah Division. This study covers three districts in Mukah Division which are Mukah, Dalat and Balingian. The main reason on the limited number of districts is the time constraints of the research study that does not allow the research study to involve any more respondents from other districts.

\section{Instrument}

According to Pal (2017), The collection of quantitative data focuses on surveys, statistics and measurement, pre-existing data and questionnaires. Therefore, the instrument for this quantitative research would be using survey questionnaires. The questionnaire contains several relevant questions, adapted and adopted from two sets of existing questionnaires. In this research study, the questionnaire is divided into three parts namely Section A for Demographic Background, Section B for Level of ICT Competency and Section C for Factors Influencing ICT Competency. The questionnaire items for Section B, level of ICT competency is derived and adapted from an existing past research from Daling (2017). The main reason on the adaptation of questionnaire from Daling is because he did the same research on identifying the level of ICT competency but using different samples and setting. Meanwhile, the items for questionnaire in section C are adopted and adapted from Lugtig and Toepoel (2016) and also from Vitanova et. al (2015). This instrument also used, a Likert Scale of 1 to 4 . Scale 1 is described as strongly disagree, scale 2 as disagree, scale 3 as agree and scale 4 as strongly agree. 


\section{Data Analysis}

The numerical data from the survey questionnaire is analysed quantitatively using SPSS Statistics version 23. Descriptive statistical method is used to analyse the data in order to answer the proposed research questions. The first research question related to level of ICT competency of ESL primary school teachers is answered by analysing the data descriptively using mean derived from the data. The second research question which is related to possible factors that impacted the ICT competency is also answered by analysing the mean acquired from the instrumentation.

\section{Data Collection}

The collection of data for this research study is as shown in a flow chart in Figure 2 below.

The data collecting procedures for this research study is brief and simple because of the time constraints and also the Movement Control Order (MCO) that refrain the movements of researchers to different districts. It is also to prevent the transmission of virus Covid-19 among the respondents. Other than that, using the Google Form as medium for distributing the survey questionnaire is also seen as convenient since it saves paper and the response is delivered directly in form of softcopy.

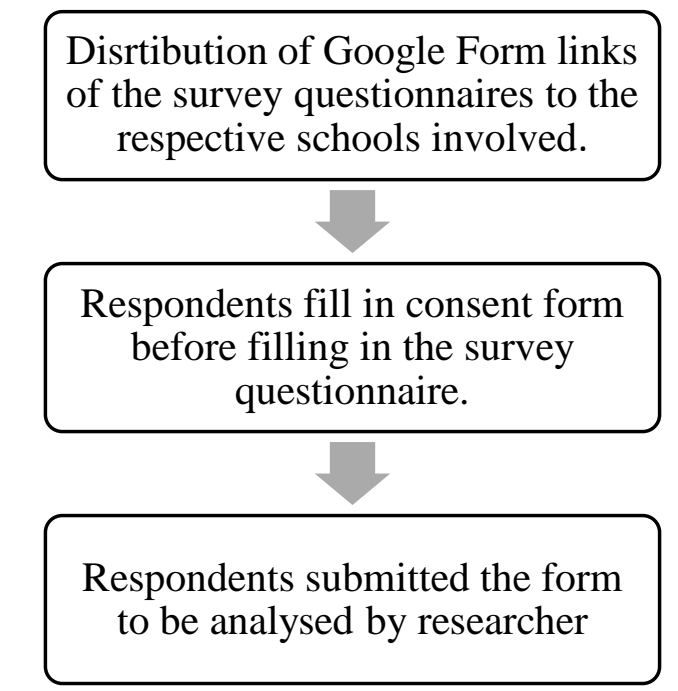

Figure 2: Flow chart for data collection procedures

\section{Validity and Reliability}

In order to ensure the reliability of the items tested in the survey questionnaire, the data collected was tabulated and analysed using SPSS version 23. It is important to tabulate and analyse data since it is used to obtain the Cronbach's Alpha reliability coefficient. Table 1 below shows the reliability statistics of survey questionnaire conducted on the ESL primary school teachers.

\begin{tabular}{ll}
\hline Cronbach's Alpha & N of Items \\
\hline 0.973 & 35 \\
\hline
\end{tabular}

Table 1: Reliability statistics of survey questionnaire 
Vol. 10, No. 1, 2021, E-ISSN: 2226-6348 @ 2021 HRMARS

Based on the data shown in Table 1, the Cronbach's Alpha value is 0.973 for the 12 items in the survey questionnaire. This value indicates that the set of items in the questionnaire certainly have a good consistency. The value is said to be consistent because according to Vaske, Beaman and Sponarski (2017), a Cronbach's Alpha value which is more than or equal to 0.8 is an excellent indication of good consistency and reliable.

\section{Findings}

Level of ICT Competency Skills as to Knowledge, Skills and Attitude of ESL Primary School Teachers

The findings for this study on level of ICT competency skills is explained in three different aspects namely knowledge, skills and attitude of the ESL primary school teachers.

\section{Level of ICT competency Skills as to Knowledge}

The table for mean and interpretation of level of ESL teachers' competency as to knowledge is as shown below in Table 2.

From the table, the indicators with highest mean belongs to knowledge on internet which is 2.68 and interpreted as developing level. The indicator with smallest mean belongs to graphics and publishing software which is 1.12 respectively and interpreted as developing level. The average mean for the level of ICT competency as to knowledge is 2.00 which is interpreted as developing level. This developing level also meant that the respondents mostly chose seldom as the frequency of use on indicators such as spreadsheets, graphics and publishing software. This also indicates that the respondents or ESL primary school teachers still have room for improvements on the knowledge aspects of ICT competency.

\begin{tabular}{llc}
\hline \multicolumn{1}{c}{ Indicators } & Mean & Interpretation \\
\hline Word processing (e.g., word) & 2.22 & $\mathrm{P}$ \\
Spreadsheets (e.g., Excel) & 2.00 & $\mathrm{D}$ \\
Graphics (e.g., Photoshop) & 1.12 & $\mathrm{D}$ \\
$\begin{array}{l}\text { Presentation software (e.g., } \\
\text { PowerPoint }\end{array}$ & 2.40 & $\mathrm{P}$ \\
Internet & 2.68 & $\mathrm{P}$ \\
Email & 2.50 & $\mathrm{P}$ \\
Publishing Software (e.g., Publisher) & 1.12 & $\mathrm{D}$ \\
Average Mean & $\mathbf{2 . 0 0}$ & Developing \\
\hline
\end{tabular}

Table 3: Level of ESL Teachers' Competency Skills as to Knowledge

(Interpretation: 3.1 - 4.0 - Excellent (E); 2.1 - 3.0-Proficient (P); 1.1 - 2.0 - Developing (D); 0.0 -1.0 - Learning(L)) 
Vol. 10, No. 1, 2021, E-ISSN: 2226-6348 @ 2021 HRMARS

\section{Level of ICT Competency Skills as to Skills}

The results on mean and interpretation of the level of ICT competency as to skills is as shown in Table 3 below.

From the table, the indicators that have the lowest mean are; I have my own computer, I install software on my own, I search teaching aids from the internet, and I create teaching aids using computer which have the mean of 2.00 and interpreted as developing level in ICT competency as to skills. The indicator which has the highest mean is I use the computer to prepare lesson plans, that is 2.56 and interpreted as proficient level. The average mean for the level of ESL competency as to skills is 2.22 which is proficient. This indicates that the respondents have proficient level in ICT competency when it comes to skills involving ICT tools.

\begin{tabular}{lcc}
\hline \multicolumn{1}{c}{ Indicators } & Mean & Interpretation \\
\hline I know computer and its functions & 2.42 & $\mathrm{P}$ \\
I repair my own computer & 2.00 & $\mathrm{D}$ \\
I install software on my own & 2.00 & $\mathrm{D}$ \\
$\begin{array}{l}\text { I search teaching aids from the } \\
\text { internet }\end{array}$ & 2.00 & $\mathrm{D}$ \\
I use the computer to prepare & 2.56 & $\mathrm{P}$ \\
$\begin{array}{l}\text { I cesson plans } \\
\text { create teaching aids using }\end{array}$ & 2.00 & $\mathrm{D}$ \\
$\begin{array}{l}\text { I always use internet to look for } \\
\text { latest additional information for } \\
\text { my lesson }\end{array}$ & 2.55 & $\mathrm{P}$ \\
$\quad$ Average Mean & $\mathbf{2 . 2 2}$ & Proficient \\
\hline
\end{tabular}

Table 3: Level of ESL Teachers' Competency as to Skills

(Interpretation: 3.1 - 4.0 - Excellent (E); 2.1 - 3.0-Proficient (P); 1.1 - 2.0 - Developing (D); 0.0

$$
\text { - } 1.0 \text { - Learning(L)) }
$$

\section{Level of ICT competency Skills as to Skills}

The results on mean and interpretation of the level of ICT competency as to attitude is as shown in Table 4 below.

From the table, the indicator that have the lowest number of means belongs to computers have proved to be effective learning tools which is only 1.77 and interpreted as developing level. This implies that the respondents seldom think that the use of computers can lead to effective learning tools. Whereas, the indicator with highest number of means is using computer make subject matter more interesting that is 2.40 and interpreted as proficient level. This indicates that the respondents sometimes believe that the use of computer makes subject matter more 
Vol. 10, No. 1, 2021, E-ISSN: 2226-6348 @ 2021 HRMARS

interesting when in come to language lesson such as English subject. The average mean for the level of ICT competency as to attitude is only 2.07 and interpreted as developing level.

\begin{tabular}{llc}
\hline \multicolumn{1}{c}{ Indicators } & Mean & Interpretation \\
\hline $\begin{array}{l}\text { Using computer make subject matter } \\
\text { more interesting }\end{array}$ & 2.40 & $\mathrm{P}$ \\
$\begin{array}{l}\text { Using computer saves time and effort } \\
\begin{array}{l}\text { Computers make individual much } \\
\text { more productive }\end{array}\end{array}$ & 2.15 & $\mathrm{P}$ \\
$\begin{array}{l}\text { Computer helps organize workload } \\
\begin{array}{l}\text { Computers have proved to be } \\
\text { effective learning tools }\end{array}\end{array}$ & 2.10 & $\mathrm{P}$ \\
$\begin{array}{l}\text { Computers help enhance students' } \\
\text { learning }\end{array}$ & 2.00 & $\mathrm{P}$ \\
\begin{tabular}{l} 
Using computer is enjoyable \\
\multicolumn{1}{c}{ Average Mean }
\end{tabular} & 2.00 & $\mathrm{D}$ \\
\hline
\end{tabular}

Table 4: Level of ESL Teachers' Competency as to Attitude

(Lagend: 3.1 - 4.0 - Excellent (E); 2.1 - 3.0 -Proficient (P); 1.1 - 2.0 - Developing (D); 0.0 - 1.0 Learning(L))

\section{Factors Influencing ICT Competency among ESL Primary School Teachers}

After analysing the date acquired from the survey questionnaire, the data is tabulated in two different constructs which are teachers' attitudes and accessibility and technical support.

\section{Teachers' Attitudes}

The first factor is teachers' attitude which is related to the teachers' attitudes in the use of ICT that reflects on their ICT competency level. The data for this factor is tabulated and shown in Table 5 below.

Based on the table, the item that has the lowest number of means is "If something goes wrong with my computer, I know how to fix it", which is only 1.02 and it indicates that majority of the respondents are strongly disagree with this item. It also means that the respondents or the ESL teachers do not know how to fix their computers if anything goes wrong with it. The item with the highest number of means is "The use of computer or any ICT tools are stressing me out", which is 3.00 and interpreted as the respondents strongly agree with the statement. Overall, the average mean for the teachers' attitude is 2.00 that is interpreted as disagreement from the respondents on the items 
Vol. 10, No. 1, 2021, E-ISSN: 2226-6348 @ 2021 HRMARS

\begin{tabular}{|c|c|c|}
\hline Items & Mean & Interpretation \\
\hline $\begin{array}{l}\text { It is very important for me to do my } \\
\text { work using my computer. }\end{array}$ & 2.56 & $A$ \\
\hline $\begin{array}{l}\text { I think playing or working with a } \\
\text { computer is very interesting and fun. }\end{array}$ & 2.06 & $A$ \\
\hline $\begin{array}{l}\text { I feel comfortable using ICT as a tool in } \\
\text { teaching and learning English language }\end{array}$ & 2.22 & $A$ \\
\hline $\begin{array}{l}\text { The use of computer or any ICT tools } \\
\text { are stressing me out }\end{array}$ & 3.00 & SA \\
\hline $\begin{array}{l}\text { If something goes wrong with my } \\
\text { computer, I know how to fix it. }\end{array}$ & 1.02 & SD \\
\hline $\begin{array}{l}\text { The use of ICT in teaching and learning } \\
\text { English language is conducive for pupils } \\
\text { to learn language because it is not easy } \\
\text { for to use. }\end{array}$ & 1.14 & $\mathrm{D}$ \\
\hline $\begin{array}{l}\text { The use of ICT helps pupils to } \\
\text { understand concept in learning English } \\
\text { language better and more effective. }\end{array}$ & 2.00 & $\mathrm{D}$ \\
\hline Average Mean & 2.00 & Disagree \\
\hline
\end{tabular}

Table 5: Teachers' attitudes

(Legend: $3.1-4.0$ - Strongly Agree (SA); 2.1 - 3.0 - Agree (A); 1.1 - 2.0 - Disagree (D); $0.0-1.0$ - Strongly Disagree (SD))

\section{Accessibility and Technical Support}

The second factor is accessibility and technical support which is related to the teachers' attitudes in the use of ICT that reflects on their ICT competency level. The data for this factor is tabulated and shown in Table 6 below.

Based on the table, the item that has the lowest mean is "The administrators provided enough time for integration of ICT tools in my English language class", which is only 1.62 and interpreted as most of the respondents disagree with this statement. This also implies that the ESL teachers did not have enough time for integration of ICT tools in their English language class. The highest mean belongs to item "There is a problem with lack of software or websites that support my English language teaching", which is 2.50 and interpreted as most of the respondents agree with the statement in this item. The ESL teachers agree that there is a lack of software or websites that support their English language lesson and it limits their development for ICT competency. Overall, the average mean for this factor is 2.08 that indicates the respondents are disagreeing with most of the items in the questionnaire relating to this factor. It also indicates that there is a problem in the accessibility and technical support aspects in school which leads to the limitation of development for ICT competency among ESL primary school teachers. 
Vol. 10, No. 1, 2021, E-ISSN: 2226-6348 @ 2021 HRMARS

\begin{tabular}{|c|c|c|}
\hline Items & Mean & Interpretation \\
\hline $\begin{array}{l}\text { The administrators equipped my } \\
\text { classroom with ICT tools for learning } \\
\text { English (computer, overhead } \\
\text { projector, speakers) }\end{array}$ & 1.96 & D \\
\hline $\begin{array}{l}\text { The administrators provided enough } \\
\text { time for integration of ICT tools in my } \\
\text { English language class }\end{array}$ & 1.62 & D \\
\hline $\begin{array}{l}\text { The school authorities provided } \\
\text { sufficient ICT tools and software for } \\
\text { teaching and learning process. }\end{array}$ & 2.00 & D \\
\hline $\begin{array}{l}\text { Regular internet access at school is } \\
\text { provided }\end{array}$ & 2.00 & D \\
\hline $\begin{array}{l}\text { There is enough support team for } \\
\text { preparing electronic materials }\end{array}$ & 2.20 & A \\
\hline $\begin{array}{l}\text { There is a problem with lack of } \\
\text { software or websites that support my } \\
\text { English language teaching }\end{array}$ & 2.50 & A \\
\hline $\begin{array}{l}\text { The use of ICT helps pupils to } \\
\text { understand concept in learning } \\
\text { English language better and more } \\
\text { effective. }\end{array}$ & 2.34 & A \\
\hline Average Mean & 2.08 & Disagree \\
\hline
\end{tabular}

Table 6: Accessibility and technical support

(Interpretation: 3.1 - 4.0 - Strongly Agree (SA); 2.1 - 3.0 - Agree (A); 1.1 - 2.0 - Disagree (D);

$$
0.0-1.0-\text { Strongly Disagree (SD)) }
$$

\section{Discussion}

The discussion of this research study is further explained to answer the research questions of the research study.

\section{RQ 1: What is the level of ICT competency among ESL primary school teachers?}

The first research question is on the level of ICT competency among ESL primary school teachers and the answer for this question is the ESL primary school teachers have ICT competency from developing to proficient level of ICT competency. This is as perceived by the findings for the research study that showed the ESL teachers have developing level on ICT competency as to knowledge and attitudes and proficient level on ICT competency as to skills. This also means that the ESL teachers have the required skills for ICT competency but they still lack and need to develop on their knowledge and attitudes on ICT competency.

Apart from that this also indicates that the findings for the current research study supports the past study from Kasemsap (2018), as there is still a need for society nowadays to 
improve on their digital literacy and ICT competency in order to compete with one another in self-development as to ICT. By looking at the level of competency of the ESL teachers, there is still a need of ESL teachers to develop their ICT competency level as it helps to improve on their teaching practices.

The findings of this study also support another past research by Santiañez, Gumabay and Pizarro (2019) which agreed on the indication of ICT competency that is based on frequency of use for the ICT tools. The survey questionnaire for current research study has used the Likert Scale of frequency to answer items provided in the questionnaire. It means both research in present and past caters to the frequency of use on ICT to measure the level of ICT competency on the sample of study. However, the study by Santiañez, Gumabay and Pizarro (2019) used an application called E-Assessment in order to assess the samples' ICT competency whilst the current study only used the questionnaire adapted from past studies. Therefore, the final results of both researches might vary and have different accuracy.

Since the findings give interpretation that the level of ICT competency among ESL primary school teachers are from developing to proficient level, there is still a need for ESL teachers to have continuous training on the use and integration of ICT tools in their lessons. These findings also supported statement from Aziz and Rahman (2017) that the continuous training is essential to polish more on teachers' blending and adaptation of ICT tools in their lessons. They also mentioned that the need of continuous training is affected by the growth of new technology day by day and this growth forces teachers to always continue being trained to upgrade their competency in ICT. Even though the target group for NorShakirah Aziz and Norizzati Rahman research is for indigenous school teachers, their findings are still valid for all teachers because the growth of ICT waits for no one. It will continue to grow along with the education system.

The result on level of ICT competency also supports the findings from a study conducted by Zainal \& Zainuddin (2020). Their latest study discussed and relates the frequent use of ICT with the quality of teaching practices of teachers. They claimed that the more teachers use ICT and integrates it with lesson, the higher the quality of their proficiency in ICT for teaching purposes. Therefore, since the level of ESL teachers in ICT competency is described as developing to proficient level, the quality of teaching using ICT tools among these teachers supposed to be high. On the opposite hand, the current study has quite a small sample of study, so the statement can still vary based on how big the sample of study on the level of competency among ESL primary school teachers. If the sample is bigger, different perspective on the use of ICT will occur and other factors will have to be considered when involving a bigger sample.

\section{RQ 2: What are the factors that can influence the ICT competency among ESL primary school teachers?}

There are two factors that has been determined based on the survey questionnaire conducted on the ESL primary school teachers, which are teachers' attitudes and also the accessibility and technical support given to the ESL teachers to support their ESL classroom.

\section{Teachers' Attitudes}

The first factor that can influence the ICT competency among ESL primary school teacher is teachers' attitudes. The findings on this particular factor resulted in majority of the respondents 
disagree on the items that are mentioned in section $C$ of the survey. This means the most of the respondents have a negative attitudes and acceptance in ICT tools for their ESL teaching practices.

Teachers' attitudes are strongly related on the readiness and acceptance on the ICT tools and integration of ICT in classroom by the teachers themselves. The findings of this research are supporting past study from Kamaruddin et al. (2017), which concluded in his study that the readiness and attitudes of teachers in accepting ICT into teaching practices affected the performance and competence in using ICT during lessons. Therefore, based on the negative findings for the current research, the ESL teachers' performance and competence in using ICT during lessons will be affected. This is also reflected on the level of ICT competency among the ESL primary school teachers that only resulted in developing to proficient level. However, the focus group of the past research by Kamaruddin et al. is different from the current research's focus group. The differences in samples or respondents have an impact on the differences in perceptions on readiness of ICT integration and competence.

Another aspect to be highlighted from this factor is, on how positivity can affect such things as competency in ICT and also the improvement of teaching practices along with the quality of teaching. Unfortunately, the respondents for this research display negative attitudes from their response regarding the use and integration of ICT tools in their lessons. If the ESL teachers keep their negative attitudes on the use of ICT tools, they eventually failed to keep up with the ever-changing ICT policy in the education system. The findings of this study support past research by Kalra (2018), whereby his findings resulted in some teachers claimed that they think the software and ICT tools have no use in their language teaching practise. This also indicates that the respondents displayed negative attitudes on ICT tools integration in lessons. Even though the past research and current research are conducted in different context, the gist from both studies still indicates that negativity of the acceptance of integration of ICT is bad for the development on teaching practices of the teachers.

\section{Accessibility and Technical Support}

The second factor that has influence on the ICT competency among ESL primary school teachers is the accessibility and technical support for the ICT tools. The findings for this factor mostly showed lower mean and indicates most of the respondents have disagree with the statements included in the questionnaire in context of accessibility and technical support. The items in the questionnaire on accessibility and technical support mainly focused on the role of administrators in providing access to internet and ICT tool and also providing the technical support for the ESL teachers in language lessons. Since the respondents mainly disagree, the administrators have proved to be non-functional in terms of accessibility and providing technical support for the teachers.

The accessibility and technical support when integrating ICT tools in teaching is necessary for teachers especially when teaching language. The findings from the current study also supported a past research conducted by Aziz and Rahman (2017), which claimed that their findings had resulted in teachers giving negative feedbacks on ICT facilities in their school as well as problems in setting up the ICT tools in their classroom that took longer time, thus affecting the provided time for their lessons. These feedbacks proved that the problem in accessibility and 
technical support existed since 2017 and based on responses in current research, the teacher still agree with the accessibility and technical support problem in their working station, which is school. But the argument for this statement is, Wei et al. (2016) stated that there is continuous support on ICT tools from the government and it is up to teachers' acceptance to integrate the tools in teaching and learning process. If the continuous support on ICT tools and software is being implemented, the teachers will not have any negative feedbacks in accessibility and technical support on ICT tools as mentioned in past research by NorShakirah Aziz and Norizzati Rahman and in current research. In addition, all three research studies are conducted in same country, using the same education system. Therefore, the context of study is more or less the same and still affect the teaching and learning in classrooms.

The findings on this factor also supports past study by Cheok et al. (2017), which has concluded the findings of their study by stating that administrators play vital roles in ensuring the eloquence of access on ICT tools or software in schools. They also have to maintain the technical support that can be provided to ease the teachers' lessons. This past research also complies with the current research's findings and supports that accessibility and technical support is essential in preserving the ICT competency among teachers. ESL teachers can only polish their ICT competency by applying the skills into lessons and in order to be able to do that, teachers need to have decent access to ICT tools and software. They also need undivided technical support whether it is from school administrators or the higher ups in the Ministry of Education or even the government.

\section{Conclusion and Recommendation}

The research study conducted in primary school to identify the level of ICT competency among ESL primary school teachers and to determine factors that influence the ICT competency of ESL primary school teachers. The findings of this study stated that the level of ICT competency among ESL primary school teachers are from developing to proficient level. Apart from that, the findings also addressed two factors that influence the ICT competency of ESL primary school teacher; teachers' attitudes, accessibility and technical support. This study also explained the positive impact of teachers' positive attitudes on integration of ICT in ESL classroom. Other than that, the study also proved that the accessibility and technical support is still a threat in improving ICT competency among ESL teachers, in accordance with past researches. In order to help future researchers conducting research study based on the same context, there are some recommendations. The recommendation is to conduct researches focusing more into two aspects or context involving level of ICT competency skills which are the knowledge and attitude of ESL primary school teachers on the ICT integration in ESL classroom. Another beneficial recommendation would be to conduct research on the usefulness or to study the roles of administrators and policy makers in ensuring the progression on ICT competency skills of ESL primary school teachers. By conducting a study on this matter would eventually revise the effectiveness of roles on the school administrators and policy makers in the ICT matters.

There are three major implications or contributions of this research in the context of ICT and ESL classroom. The first implication of this research is, it raised awareness among ESL teachers to improve on their ICT competency skills in order to upgrade their ESL classroom. This study has been able to identify the level of ICT competency skills among ESL primary school 
teachers. Therefore, the level of ICT competency skills can be used as guidance for the ESL teachers to improve on their ICT competency skills in order to use their skills in the ESL classroom. Other than that, the second implication of this study is, it can help the administrators to be aware on the importance of the ESL teachers' improvement in ICT competency skills. If the administrators are aware of the level of ICT competency skills of the ESL teachers, they will be able to inculcate more ICT integration in ESL classroom, thus improving the quality of ESL learning and teaching practises. Last but not least, this research has proved that the involvement of administrators is crucial in providing necessities to ensure the development of level of ICT competency skills among the ESL primary school teachers.

\section{References}

Anas, I., \& Musdariah, A. (2018). JELTL (Journal of English Language Teaching and Linguistics), 3(1), 2503-1848.

Cheok, M. L., Wong, S. L., Ayub, A. F., \& Mahmud, R. (2017). Teachers' Perceptions of E Learning in Malaysian Secondary Schools. Malaysian Online Journal of Educational Technology, 5(2), 20-33

Daling, R. (2017). International Journal of Education and Research 5(11).

Etikan, I., Musa, S. A., \& Alkassim, R. S. (2016). Comparison of convenience sampling and purposive sampling. American journal of theoretical and applied statistics, 5(1),1-4.

Guillo Jr, R. M., \& Guillo, R. M. (2017). Assessment of Information Communication Technology (ICT) Competency of Teachers and Students at Batangas State University. International Journal of Contemporary Applied Sciences, 4(4), 37- 47.

Kalra, R. (2018). Experienced and Novice Teachers' Awareness and Attitudes towards ICT in Language Classroom: A study conducted in a Thai context. Arab World English Journal (AWEJ) Special Issue on CALL, (4).

Kamaruddin, K., Abdullah, C. A. C., \& Idris, M. N. (2017). Integrating ICT in teaching and learning: A preliminary study on Malaysian private preschool. International Journal of Academic Research in Business and Social Sciences, 7(11), 1236-1248.

Kasemsap, K. (2018). Encouraging digital literacy and ICT competency in the information age In Encyclopedia of Information Science and Technology, Fourth Edition 2253-2263.

Lugtig, P., \& Toepoel, V. (2016). The use of PCs, smartphones, and tablets in a probabilitybased panel survey: Effects on survey measurement error. Social Science Computer Review 34(1): 78-94.

Luque, J., Abdurrahman, S. F., \& Prakosa, P. W. B. (2020). Competency Standards as a Tool for Human Capital Development: Assessment of their Development and Introduction into TVET and Certification in Indonesia 1-64.

Ministry of Education Malaysia. 2013. Malaysia Education Blueprint 2013 - 2025 (Preschool to Post - Secondary Education).

Aziz, N. S., \& Rahman, N. (2017). Use of ICT in indigenous primary school classroom: A case study of teachers' expectations and experiences. In 2017 International Conference on Research and Innovation in Information Systems (ICRIIS) (pp. 1-4). IEEE. 
Santiañez, R. M., Gumabay, M. V. N., \& Pizarro, J. B. E-Assessment Application using A Decision-Tree in Predicting Teachers' Information and Communication Technology (ICT) Competency Level.

Vitanova, V., Atanasova-Pachemska, T., Iliev, D., \& Pachemska, S. (2015). Factors affecting the development of ICT competencies of teachers in primary schools. Procedia-Social and Behavioral Sciences 191,1087-1094.

Vaske, J. J., Beaman, J., \& Sponarski, C. C. (2017). Rethinking Internal Consistency in Cronbach's Alpha. Leisure Sciences 39(2): 167-173.

Zainal, A. Z., \& Zainuddin, S. Z. (2020). Technology adoption in Malaysian schools: Ananalysis ofnational ICT in education policy initiatives. Digital Education Review, (37), 172-194. 